\title{
Chronic Ethanol Administration to Rats Decreases Receptor-operated Mobilization of Intracellular Ionic Calcium in Cultured Hepatocytes and Inhibits 1,4,5-inositol Trisphosphate Production: Relevance to Impaired Liver Regeneration
}

\author{
Bao-Hong Zhang, Brian P. Horsfield and Geoffrey C. Farrell \\ Storr Liver Unit, Department of Medicine, University of Sydney at Westmead Hospital, Westmead, NSW, Australia 2145
}

\begin{abstract}
We tested the hypothesis that ethanol impairs liver regeneration by abrogating receptor-mediated elevation of cytosolic free calcium $\left\{\left[\mathrm{Ca}^{2+}\right]_{i}\right\}$. In rats fed for 16 weeks with ethanol, hepatocellular proliferation induced by partial hepatectomy was greatly impaired. Similarly, EGF-induced DNA synthesis was reduced in cultured hepatocytes from ethanol-fed rats. There was no change in the number or affinity of EGF receptors on hepatocytes from ethanol-fed rats. Despite this, EGF-mediated production of inositol 1,4,5-trisphosphate $\left(\operatorname{Ins}[1,4,5] P_{3}\right)$ was lower in hepatocytes from ethanolfed rats, and the EGF-induced $\left[\mathrm{Ca}^{2+}\right]_{i}$ transient appeared to be abrogated. When vasopressin or phenylephrine were used as cell surface receptor ligands, hepatocytes cultured from ethanol-fed rats exhibited major reductions in $\operatorname{Ins}(1,4,5) P_{3}$ synthesis. This was associated with greatly truncated $\left[\mathrm{Ca}^{2+}\right]_{\mathrm{i}}$ transients. These changes were not due to an effect on the $\operatorname{Ins}(1,4,5) P_{3}$ receptor on the endoplasmic reticulum or to a decrease in the size of the $\operatorname{Ins}(1,4,5) P_{3}$-mobilizable intracellular $\mathrm{Ca}^{2+}$ store. Further, mobilization of the same $\mathrm{Ca}^{2+}$ store by 2,5-di-tert-butylhydroquinone or thapsigargin restored the ability of hepatocytes from ethanol-fed rats to proliferate when exposed to EGF. It is concluded that chronic ethanol consumption inhibits liver regeneration by a mechanism that is, at least partly, the result of impaired receptor-operated $\left[\mathrm{Ca}^{2+}\right]_{\mathrm{i}}$ signaling due to reduced generation of $\operatorname{Ins}(1,4,5) P_{3}$. (J. Clin. Invest. 1996. 98:1237-1244.) Key words: liver regeneration - receptor-mediated signal transduction • inositol 1,4,5-trisphosphate - alcohol consumption $\cdot$ cell culture $\bullet$ hepatocytes
\end{abstract}

\section{Introduction}

After a variety of hepatic injuries, the capacity of the liver to recover is largely due to regenerative growth. In rats, resection

This work was presented at the May 1995 meeting of the American Association for the Study of Liver Diseases and has been published in abstract form: Gastroenterology 1995; 108;A 1210.

Address correspondence to Geoffrey C. Farrell, Storr Liver Unit, Westmead Hospital, Westmead, NSW 2145, Australia. Phone: 612845-7705. FAX: 612-635-7582. e-mail: gfstorr@WESTMED.WH.SU. edu.AU

Received for publication 6 June 1995 and accepted in revised form 11 July 1996.

J. Clin. Invest.

(C) The American Society for Clinical Investigation, Inc.

0021-9738/96/09/1237/08 \$2.00

Volume 98, Number 5, September 1996, 1237-1244 of $70 \%$ of the hepatic mass invokes a regenerative response that restores the original organ weight by $7-14 \mathrm{~d}(1,2)$. At the cellular level, hepatocytes are transformed from their predominantly resting (growth-arrested, $\mathrm{G}_{0}$ ) state to enter the cell cycle and proliferate in a coordinated wave of DNA synthesis that is evident $20-24 \mathrm{~h}$ after liver resection.

Alcoholic liver disease is a major cause of liver disease in Western countries. A typical feature of the clinical course is slow recovery of patients after an episode of alcoholic hepatitis. This has been attributed, at least in part, to ethanol-induced impairment of liver regeneration. Thus it has been established experimentally that chronic ethanol inhibits hepatic growth in vivo (3-7) and in vitro (8-10), but the mechanism by which ethanol inhibits liver regeneration is poorly understood.

In many rapidly turning-over cell types, including fibroblasts $(11,12)$ and epithelioid tumor cell lines (13-15), intracellular $\mathrm{Ca}^{2+}$ and $\mathrm{pH}$ signals are essential for the transition of resting cells to the proliferative state. In hepatocytes, occupancy of several growth factor and hormone receptors induces transient elevation of the cytosolic free calcium $\left\{\left[\mathrm{Ca}^{2+}\right]_{\mathrm{i}}\right\}{ }^{1}$ Thus, EGF, hepatocyte growth factor, vasopressin, and the $\alpha_{1}$ adrenergic receptor agonist, phenylephrine, all induce increases in $\left[\mathrm{Ca}^{2+}\right]_{\mathrm{i}}$. The mechanism of agonist receptor-mediated elevation of $\left[\mathrm{Ca}^{2+}\right]_{\mathrm{i}}$ is via the second messenger inositol 1,4,5-trisphosphate $\left(\operatorname{Ins}[1,4,5] P_{3}\right)$, which is formed as a result of the guanine nucleotide-binding regulatory protein ( $\mathrm{G}$ protein)-dependent activation of a phospholipase $\mathrm{C}\left(\mathrm{PLC} \beta_{1}\right)$ that specifically cleaves phosphatidylinositol 4,5-bisphosphate $\left(\mathrm{PIP}_{2}\right)$. In the case of EGF, occupancy of EGF receptor generates Ins $(1,4,5) P_{3}$ by activation of PLC $\gamma_{1}$, a process which involves the activated receptor directly in most cell types, but which may involve a G-protein in hepatocytes (16). Ins $(1,4,5) P_{3}$ elevates $\left[\mathrm{Ca}^{2+}\right]_{\mathrm{i}}$ by releasing stored $\mathrm{Ca}^{2+}$ from a subfraction of the endoplasmic reticulum, hereafter referred to as the $\operatorname{Ins}(1,4,5) P_{3^{-}}$ mobilizable internal $\mathrm{Ca}^{2+}$ store (17). This process, combined with receptor-stimulated $\mathrm{Ca}^{2+}$ influx, leads to an increase in $\left[\mathrm{Ca}^{2+}\right]_{\mathrm{i}}$ that is involved with the production of many physiological responses in the cell, including growth and proliferation $(18,19)$.

We postulated that ethanol might inhibit hepatocellular proliferation by impairing mitogen receptor-mediated $\left[\mathrm{Ca}^{2+}\right]_{i}$ signal tranduction. The objectives of the present study, therefore, were $(a)$ to investigate the long-term effects of ethanol feeding on the $\left[\mathrm{Ca}^{2+}\right]_{\mathrm{i}}$ signals induced by EGF, vasopressin,

1. Abbreviations used in this paper: $\left[\mathrm{Ca}^{2+}\right]_{\mathrm{i}}$, cytosolic free calcium; fura-2/AM, 1-[2-(5-carboxyoxazol-2-yl)-6-aminobenzofuran-5-oxy]2-(2'-amino-5'-methylphenoxy) ethane- $N N N^{\prime} N^{\prime}$-tetra-acetoxymethyl ester; $\operatorname{Ins}(1,4,5) \mathrm{P}_{3}$, inositol 1,4,5-trisphosphate; $\mathrm{PIP}_{2}$, phosphatidylinositol 4,5-bisphosphate; PLC, phospholipase C; tBHQ, 2,5-ditert-butylhydroquinone. 
and phenylephrine in cultured rat hepatocytes, and $(b)$ to characterize the relationship between changes in $\left[\mathrm{Ca}^{2+}\right]_{i}$ signals and hepatocyte proliferation after chronic exposure to alcohol.

\section{Methods}

Chemicals. Arginine vasopressin, phenylephrine, ribonuclease (RNase), Ins $(1,4,5) P_{3}$, 2,5-di-tert-butylhydroquinone, thapsigargin, BSA, saponin, DMSO, and cell culture medium components were purchased from Sigma Chemical Co. (St. Louis, MO). Collagenase (type II) was from Worthington Biochemicals (Freehold, NJ). EGF was from Collaborative Research Inc. (Bedford, MA). 1-[2-(5-carboxyoxazol-2-yl)-6-aminobenzofuran-5-oxy]-2-(2-amino-5'-methylphenoxy) ethane- $N N N^{\prime} N^{\prime}$-tetra-acetoxymethyl ester (fura-2/AM) and pluronic F-127 were obtained from Molecular Probes (Eugene, OR). Collagen I and ionomycin (free acid) was from Boehringer Mannheim Australia Pty Ltd. (Sydney, Australia). $\left[{ }^{3} \mathrm{H}\right]$ Thymidine and ${ }^{125} \mathrm{I}-$ EGF were purchased from Amersham Australia (Sydney, Australia). $\left[{ }^{3} \mathrm{H}\right]$ Inositol 1,4,5-trisphosphate, $\left[{ }^{3} \mathrm{H}\right]$ inositol 1,3,4-trisphosphate standards, and myo- $\left[1,2-{ }^{3} \mathrm{H}\right]$ inositol were from Du Pont-New England Nuclear Corp. (Boston, MA). All other miscellaneous chemicals and solvents were at least analytical reagent grade; they were purchased from Ajax Chemicals (Sydney, Australia). Matrigel was prepared inhouse by extraction from Engelbreth-Holm-Swarm sarcoma propagated in C57BL/6 female mice, as previously described (20).

Animal model. This study was approved by the Animal Ethics Committee of the Western Sydney Area Health Service and experiments conformed to the highest international standards of humane care. Male Wistar rats, initial weight 180-220 grams, were obtained from the Westmead Hospital animal house. Animals were housed in individual cages under conditions of constant temperature $\left(22^{\circ} \mathrm{C}\right)$ and humidity. They were kept on a $12 \mathrm{~h}$ light/dark cycle (light on 0600 to $1800 \mathrm{~h}$ ) and acclimatized to the housing situation for one week before experiments.

Rats were divided into three groups. Animals in group A were fed commercial rat pellets (Allied Food, Sydney, Australia) and were induced to consume $40 \%$ ethanol in water, by introducing ethanol into the drinking water gradually, over $10 \mathrm{wk}$ (21). An intake of $15 \mathrm{~g}$ ethanol $/ \mathrm{kg} / \mathrm{d}$ was achieved, as a result of which ethanol was estimated to account for $39 \%$ of total ingested kilojoules. As reported elsewhere (21), the serum ethanol concentration of the ethanol-consuming rats was regularly above $20 \mathrm{mM}$, and these blood levels were maintained throughout the day. After $16 \mathrm{wk}$ on the diet, body weight in ethanol and pair-fed rats (group B, see below) was comparable, and histology showed that the livers of ethanol-fed rats developed steatosis without obvious inflammation, hepatocyte necrosis or fibrosis (21). Rats in group B were pair-fed isocaloric quantities of the same diet as the ethanol-fed group, but dextrose was substituted for ethanol. Group C animals were allowed ad libitum access to the commercial rat pellets.

Partial hepatectomy. After $16 \mathrm{wk}$ on the diets, and under ether anesthesia, four rats from each group were subjected to $68 \%$ partial hepatectomy according to method of Higgins and Anderson (22). Another four rats from each group were subjected to a sham operation. Animals were killed at $24 \mathrm{~h}$ after partial hepatectomy or sham operation. $2 \mathrm{~h}$ before use, the rats were injected intraperitoneally with $\left[{ }^{3} \mathrm{H}\right]$ thymidine in $0.15 \mathrm{M} \mathrm{NaCl}(250 \mu \mathrm{Ci} / \mathrm{kg}$ body wt; total volume $\sim 0.8 \mathrm{ml}$, sp act $48 \mathrm{Ci} / \mathrm{mmol})$. The incorporation of $\left[{ }^{3} \mathrm{H}\right]$ thymidine into DNA was examined, as described below.

Determination of $\left[{ }^{3} H\right]$ thymidine incorporation into DNA. A $0.1-$ $0.2 \mathrm{~g}$ portion of the caudate lobe of the liver was used to determine $\left[{ }^{3} \mathrm{H}\right]$ thymidine incorporation into DNA. Total nucleic acid (tNA) was prepared by the method of Durnam and Palmiter (23). RNA was destroyed by addition of RNase $(100 \mu \mathrm{g} / \mathrm{ml}$, DNase free) to the tNA and incubation at $37^{\circ} \mathrm{C}$ for $1 \mathrm{~h}$. Hepatic DNA was precipitated by icecold absolute ethanol for the measurement of total DNA assay and the radioactivity assay using the method as described previously (24).
Isolation and culture of hepatocytes. After $16 \mathrm{wk}$ on the diets, hepatocytes were isolated from ether-anesthetized rats by a nonrecirculating collagenase perfusion through the portal vein, according to the method of Bissell and Guzelian (25), as described previously (24). Freshly isolated hepatocytes were plated on to 30 or $60 \mathrm{~mm}$ culture dishes for the purpose of experiments, as detailed below. Cells were then incubated at $37^{\circ} \mathrm{C}$ in a humidified atmosphere of air containing $5 \% \mathrm{CO}_{2}$. Three hours after plating, the medium was changed to remove the unattached hepatocytes.

$\left[{ }^{3} H\right]$ Thymidine incorporation into hepatic DNA in cultured hepatocytes. Hepatocytes $\left(0.85 \times 10^{6}\right.$ in $3.0 \mathrm{ml}$ of modified medium $)$ were plated on $60 \mathrm{~mm}$ collagen I-coated culture dishes. After initial medium change, EGF $(10 \mathrm{ng} / \mathrm{ml})$ was added to the medium containing insulin $(1 \mathrm{mg} / \mathrm{liter})$, optimal ionic concentrations of $\mathrm{Ca}^{2+}(0.9 \mathrm{mM})$ and $\mathrm{HCO}_{3}{ }^{-}(35 \mathrm{mM})$ for DNA synthesis $(24) .\left[{ }^{3} \mathrm{H}\right]$ Thymidine $(2 \mu \mathrm{Ci} /$ $\mathrm{ml}$, sp act $25 \mathrm{Ci} / \mathrm{mmol}$ ) was added to the medium $48 \mathrm{~h}$ after the initial medium change, and hepatocytes were harvested $24 \mathrm{~h}$ later for DNA extraction. $\left[{ }^{3} \mathrm{H}\right]$ Thymidine incorporation was determined as described elsewhere (24); we have previously demonstrated that $\left[{ }^{3} \mathrm{H}\right]$ thymidine incorporation in this system largely represents replicative DNA synthesis (24).

EGF receptor assay. Hepatocytes $\left(0.5 \times 10^{6}\right.$ cells in $2.0 \mathrm{ml}$ of modified medium) were plated on $30 \mathrm{~mm}$ culture dishes coated with collagen I. $15 \mathrm{~h}$ after the initial medium change, ${ }^{125} \mathrm{I}$-EGF binding to hepatocytes in primary culture was performed using the method of Shi and Yager (26). The samples were counted in a LKB-Wallace gamma counter (Turku, Finland). The maximum number of binding sites $\left(B_{\max }\right)$ and the dissociation constant $\left(K_{\mathrm{d}}\right)$ were estimated by Scatchard analyses (27).

Measurement of $\left[\mathrm{Ca}^{2+}\right]_{i}$ in cultured hepatocytes. Freshly isolated hepatocytes $\left(1 \times 10^{6}\right.$ cells in $3.0 \mathrm{ml}$ of modified Waymouth medium) were plated on to $60 \mathrm{~mm}$ culture dishes containing glass coverslips coated with matrigel. $\left[\mathrm{Ca}^{2+}\right]_{i}$ was determined in cultured hepatocytes essentially as described by Grynkiewicz et al. (28). Thus, 16-18 h after cell culture, hepatocytes were incubated with Hepes buffer (in $\mathrm{mM}$ : $\mathrm{NaCl} 118, \mathrm{NaHCO}_{3} 25, \mathrm{MgSO}_{4} 1.2, \mathrm{KCl} 4.7, \mathrm{CaCl}_{2}$ 0.9, $\mathrm{KH}_{2} \mathrm{PO}_{4} 1.2$, Hepes 25, and $0.2 \%$ BSA) containing $5 \mu \mathrm{M}$ fura-2/AM (dissolved with DMSO and $0.03 \%$ pluronic $\mathrm{F} 127$ ) in an air $/ 5 \% \mathrm{CO}_{2}$ incubator for $45 \mathrm{~min}$. After three times washing, coverslips, with the attached fura-2-loaded hepatocytes, were transferred into a thermostatically controlled perfusion chamber $\left(37 \pm 0.5^{\circ} \mathrm{C}\right)$. This chamber was mounted on the stage of a Nikon Diaphot inverted microscope fitted with $\times 40$ fluor oil immersion objective. There were approximately 15 hepatocytes in each microscopic field. Cells were alternately excited at 340 and $380 \mathrm{~nm}$ wavelengths using a stepping filter wheel and emitted light was collected through a dichroic mirror and interference filters at $510 \mathrm{~nm}$. The 340/380 ratio was obtained and stored to hard disk using a PHOCAL system (Applied Imaging, Gateshead, Tyne and Wear, UK). $\left[\mathrm{Ca}^{2+}\right]_{i}$ was calculated based on calibration parameters as follows: $F_{\max }$ was obtained using ionomycin $(20 \mu \mathrm{M})$ in the presence of $10 \mathrm{mM} \mathrm{Ca}^{2+}$, and $F_{\min }$ was determined after addition of $10 \mathrm{mM}$ EGTA (pH 8.0). The $K_{\mathrm{d}}$ used for fura-2 binding of $\mathrm{Ca}^{2+}$ was $224 \mathrm{nM}$. The following formula was used to calculate $\left[\mathrm{Ca}^{2+}\right]_{\mathrm{i}}$ :

$\left[\mathrm{Ca}^{2+}\right]_{\mathrm{i}}=K\left(R-R_{\min }\right) /\left(R_{\max }-R\right)$

where $\mathrm{R}$ is the fluorescent measurement ratio (340/380), $R_{\max }$ is the ratio when the probe is saturated with $\mathrm{Ca}^{2+}, R_{\min }$ is the ratio with no free $\left[\mathrm{Ca}^{2+}\right]_{\mathrm{i}}$ present, $K$ represents $K_{\mathrm{d}}\left(F_{\mathrm{o}} / F_{\text {sat }}\right)$, where $F_{\mathrm{o}}$ is the intensity at the upper wavelength at $R_{\min }, F_{\text {sat }}$ is the intensity of the upper wavelength at $R_{\max }$.

Extraction and separation of inositol polyphosphates using HPLC. After initial medium change, hepatocytes $\left(2 \times 10^{6}\right.$ cells per $60 \mathrm{~mm}$ matrigel-coated plate) were incubated in a medium containing myo- $\left[1,2-{ }^{3} \mathrm{H}\right]$ inositol $(5 \mu \mathrm{Ci} / \mathrm{ml})$ for $15 \mathrm{~h}$. Cells were washed twice with PBS, and then incubated in a medium containing $10 \mathrm{mM} \mathrm{LiCl}$ $(\mathrm{pH} 7.2)$ at $37^{\circ} \mathrm{C}$ for $30 \mathrm{~min}$. The reaction was started by addition of $10 \mathrm{nM}$ EGF, or $20 \mathrm{nM}$ vasopressin, or $20 \mu \mathrm{M}$ phenylephrine and ter- 
minated at various times after addition by aspiration of the medium and the addition of ice-cold PBS. Inositol polyphosphates was extracted using the method as described by Hansen et al. (29). The determination of protein was performed according to method of Lowry (30).

Inositol polyphosphates were separated and analyzed by HPLC according to the method of Hansen et al. (29) with minor modification. The calibration was performed using the method essentially as described by Johnson et al. (31). The retention times of the standards were: $\left[{ }^{3} \mathrm{H}\right] \operatorname{Ins}(1,3,4) P_{3}, 35.0 \mathrm{~min} ;\left[{ }^{3} \mathrm{H}\right] \operatorname{Ins}(1,4,5) P_{3}, 37.0 \mathrm{~min}$. Fractions were counted for ${ }^{3} \mathrm{H}$ radioactivity after addition of $5 \mathrm{ml}$ of ACS II scintillant (Amersham Australia, Sydney, Australia).

Statistical analysis. All results are expressed as mean \pm standard deviation. Analysis of variance (ANOVA) and Fisher's least significant method were used for comparisons among more than two means, and the Student's $t$ test was used for comparison between two means. A $P$ value $<0.05$ was considered to be significant.

\section{Results}

Effect of chronic ethanol feeding on liver regeneration after partial hepatectomy. Rats fed the diet containing 39\% of calories as ethanol in the drinking water grew normally and maintained good general condition, as detailed elsewhere (21). As shown in Fig. 1, partial hepatectomy induced the expected vigorous regenerative response in intact rats. Thus, $24 \mathrm{~h}$ after partial hepatectomy, $\left[{ }^{3} \mathrm{H}\right]$ thymidine incorporation into DNA was greatly increased compared with sham-operated controls in all groups of animals. In ethanol-fed rats, however, partial hepatectomy-stimulated $\left[{ }^{3} \mathrm{H}\right]$ thymidine incorporation was significantly lower than in pair-fed rats $(5.7 \pm 1.2 \mathrm{vs} 34 \pm 2.9 \mathrm{dpm} / \mu \mathrm{g}$ DNA, $P<0.01)$ or in ad libitum-fed controls $(26 \pm 5.8 \mathrm{dpm} / \mu \mathrm{g}$ DNA, $P<0.01)$. There was no difference between pair-fed and ad libitum-fed rats (Fig. 1).

EGF-induced DNA synthesis in hepatocytes cultured from chronic ethanol-fed rats. In the absence of mitogen, $\left[{ }^{3} \mathrm{H}\right]$ thymidine incorporation into DNA after $72 \mathrm{~h}$ cell culture was very low in primary hepatocyte cultures $\left(1-2 \times 10^{3} \mathrm{dpm} / \mu \mathrm{g}\right.$ DNA). After addition of EGF to the culture medium (final concentra-

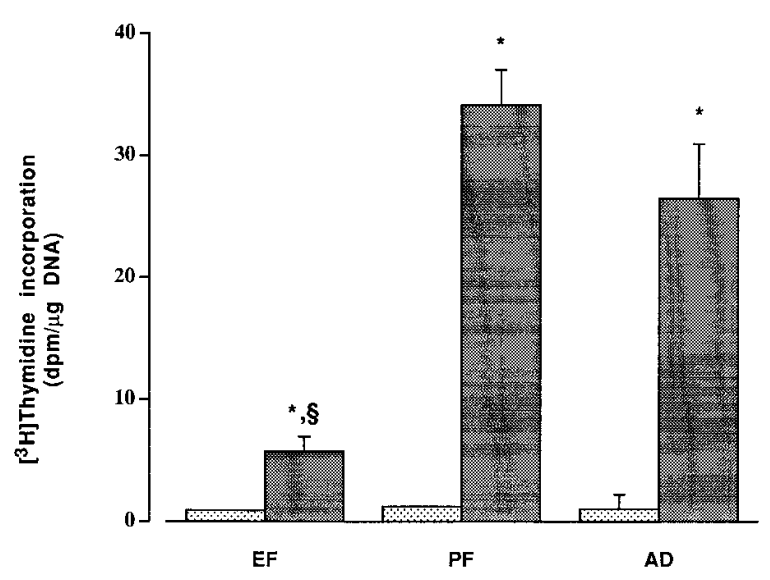

Figure 1. Hepatic incorporation of $\left[{ }^{3} \mathrm{H}\right]$ thymidine into DNA after sham operation (圈) and partial hepatectomy $(\square)$ in ethanol- $(E F)$, pair- $(P F)$, and ad libitum-fed $(A D)$ rats. Columns represent mean values and error bars are $1 \mathrm{SD}$ of four rats. $* P<0.01$ compared with corresponding sham-operated rats. ${ }^{\S} P<0.01$ compared with $\mathrm{PF}$ or $\mathrm{AD}$ rats after partial hepatectomy. tion, $10 \mathrm{ng} / \mathrm{ml}$ ), DNA synthesis was induced in all groups, but the extent of EGF-induced $\left[{ }^{3} \mathrm{H}\right]$ thymidine incorporation was significantly lower in hepatocytes from ethanol-fed rats than that of both control groups $(P<0.01$; Fig. 2$)$.

Binding of ${ }^{125}$ I-EGF to hepatocellular plasma membranes of chronic ethanol-fed rats. To examine whether changes in EGF receptor number or ligand affinity contributed to the impairment of mitogen-induced hepatocyte proliferation, binding studies were conducted using ${ }^{125} \mathrm{I}-\mathrm{EGF}$ as probe. As shown in Fig. 3, the binding curves were similar for hepatocytes from each animal group. Scatchard analysis demonstrated no significant differences either in the numbers of EGF receptors $\left(B_{\max }\right)$ or in the binding affinity $\left(K_{\mathrm{d}}\right)$ when hepatocytes from ethanol-fed rats were compared to both types of controls.

$\left[\mathrm{Ca}^{2+}\right]_{i}$ changes induced by EGF, vasopressin, and phenylephrine in hepatocytes cultured from chronic ethanol-fed and control rats. The impairment of EGF-stimulated DNA synthesis that was observed, despite the presence of unchanged numbers and affinity of EGF receptors, focussed attention on whether receptor-operated signal transduction could be a possible mechanism by which chronic ethanol feeding impairs hepatocyte proliferation. In preliminary experiments, as shown in Fig. $4(i)$, there appeared to be a reduction of the $\left[\mathrm{Ca}^{2+}\right]_{i}$ transient produced by $10 \mathrm{nM}$ EGF in ethanol-fed rat hepatocytes $(263 \pm 22 \mathrm{nM})$ compared with that in pair-fed controls $(427 \pm 47 \mathrm{nM})(P<0.01)$. It is noted, however, that the responsiveness to EGF varied between individual cells $(\sim 60 \%$ of cells responded), while the amplitude of EGF-induced $\left[\mathrm{Ca}^{2+}\right]_{i}$ transients was relatively low compared with that generated by other receptors (compare Fig. $4[i]$ with [ii], and [iii]). To elucidate more clearly the effects of chronic ethanol feeding on receptor-mediated signal transduction, additional studies were performed using vasopressin and phenylephrine as model ligands for cell surface receptor occupancy.

In contrast to EGF, essentially all cells appeared to respond to vasopressin and phenylephrine, as determined qualitatively by fluorescent microscopy. As expected in control hepatocytes (32), $20 \mathrm{nM}$ vasopressin induced a transient spike

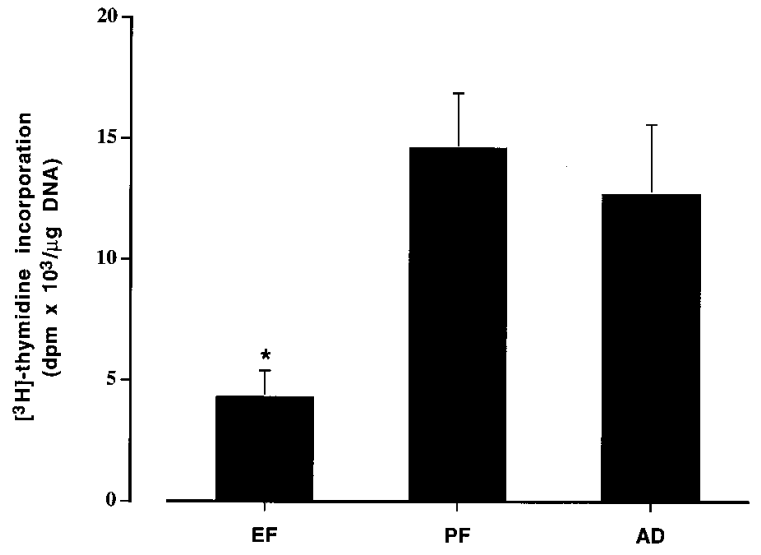

Figure 2. EGF-stimulated $\left[{ }^{3} \mathrm{H}\right]$ thymidine incorporation into DNA of cultured rat hepatocytes from ethanol- $(E F)$, pair- $(P F)$, and ad libitum-fed $(A D)$ rats. $8.5 \times 10^{5}$ cells were plated onto $60 \mathrm{~mm}$ collagen I-coated culture dishes. $2 \mu \mathrm{Ci} / \mathrm{ml}$ of $\left[{ }^{3} \mathrm{H}\right]$ thymidine was added at $48 \mathrm{~h}$ after cell culture, and cells were harvested at $72 \mathrm{~h}$. Results shown are mean \pm SD of five separate experiments, each of which was performed in triplicate. ${ }^{*} P<0.01$, as compared with $\mathrm{PF}$ and $\mathrm{AD}$ rats. 

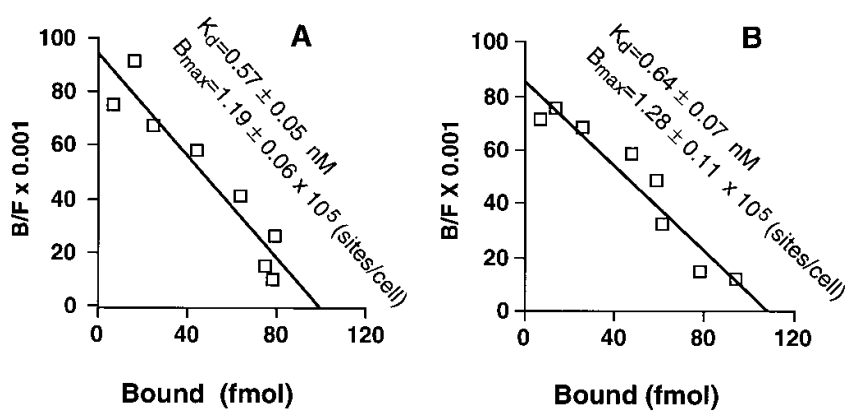

in $\left[\mathrm{Ca}^{2+}\right]_{\mathrm{i}}$ followed by a sustained increase that lasted more than 20 min (Fig. 4 [ii]). In hepatocytes from ethanol-fed rats, however, the amplitude of the $\left[\mathrm{Ca}^{2+}\right]_{\mathrm{i}}$ spike induced by vasopressin was reduced by $\sim 50 \%$ compared with pair-fed controls $(310 \pm 32 \mathrm{nM}$ vs $640 \pm 68 \mathrm{nM}$ respectively, $P<0.01)$. As shown in Fig. 4 (ii), a similar reduction in the plateau level of vasopressin-induced $\left[\mathrm{Ca}^{2+}\right]_{\mathrm{i}}$ was evident in hepatocytes from ethanol-fed rats.

In contrast to vasopressin, which induced a single spike of $\left[\mathrm{Ca}^{2+}\right]_{\mathrm{i}}, 20 \mu \mathrm{M}$ phenylephrine produced an initial $\left[\mathrm{Ca}^{2+}\right]_{\mathrm{i}}$ transient of $663 \pm 52 \mathrm{nM}$ followed by an oscillating series of troughs and peaks; these peaks had an amplitude of $608 \pm 61 \mathrm{nM}$. In hepatocytes from ethanol-fed rats, as shown in Fig. 4 [iii], the amplitude of the initial spike of $\left[\mathrm{Ca}^{2+}\right]_{i}$ was $335 \pm 47 \mathrm{nM}$, which was considerably and significantly reduced compared with pair-fed rats $(P<0.01)$. Moreover, the phenylephrine-induced oscillations of $\left[\mathrm{Ca}^{2+}\right]_{\mathrm{i}}$ observed in hepatocytes from control rats were abolished in hepatocytes from ethanol-fed rats (Fig. $4[i i i])$.

Hormone receptor-induced Ins $(1,4,5) P_{3}$ production in cultured hepatocytes from ethanol-fed and control rats. The increase in $\left[\mathrm{Ca}^{2+}\right]_{\mathrm{i}}$ that follows mitogen or hormonal occupancy of their cognate receptors is mediated via $\operatorname{Ins}(1,4,5) P_{3}(17)$. As

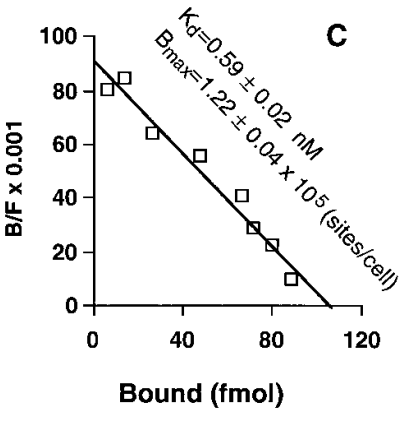

Figure 3. Scatchard analysis of ${ }^{125} \mathrm{I}-$ EGF binding to hepatocytes from ethanol-, pair-, and ad libitum-fed rats. EGF binding assays were performed as described in Methods. Data are from a representative experiment, one of replicates in which values were determined in triplicate. $K_{\mathrm{d}}$ and $B_{\max }$ are calculated from three separate experiments. $A$, ethanol-fed. $B$, pair-fed. $C$, ad libitum-fed. shown in Fig. $5 A$, addition of vasopressin, phenylephrine or EGF to pair-fed rat hepatocytes stimulated production of $\operatorname{Ins}(1,4,5) P_{3}$ within $30 \mathrm{~s}$. These increases in $\operatorname{Ins}(1,4,5) P_{3}$ reached a peak after $1 \mathrm{~min}$ of hormone additions, and then declined to basal levels after $\sim 5 \mathrm{~min}$. The maximum levels of Ins $(1,4,5) P_{3}$ (expressed as percentage of basal levels produced without addition of hormones) were $417 \pm 30 \%$ for vasopressin, $303 \pm 37 \%$ for phenylephrine and $240 \pm 20 \%$ for EGF, respectively.

The kinetics of hormone-induced $\operatorname{Ins}(1,4,5) P_{3}$ production were similar in ethanol-fed rat hepatocytes (Fig. 5 B). However, the quantum of $\operatorname{Ins}(1,4,5) P_{3}$ generation was significantly less than pair-fed rat hepatocytes at various times after addition of vasopressin, phenylephrine, or EGF. Thus, after $1 \mathrm{~min}$ addition, the production of $\operatorname{Ins}(1,4,5) P_{3}$ was $180 \pm 17 \%$, $183 \pm 15 \%$, and $150 \pm 20 \%$, for vasopressin, phenylephrine and EGF respectively. These differences compared with pair-fed controls are all significant $(P<0.01)$.

Ins $(1,4,5) P_{3}$-induced changes in $\left[\mathrm{Ca}^{2+}\right]_{i}$ in permeabilized hepatocytes. Binding of Ins $(1,4,5) P_{3}$ to its receptor on the endoplasmic reticulum results in release of $\mathrm{Ca}^{2+}$ from an intracellular store (17). To examine whether the $\operatorname{Ins}(1,4,5) P_{3}$ receptor was affected by chronic ethanol feeding, the $\left[\mathrm{Ca}^{2+}\right]_{i}$ changes in-

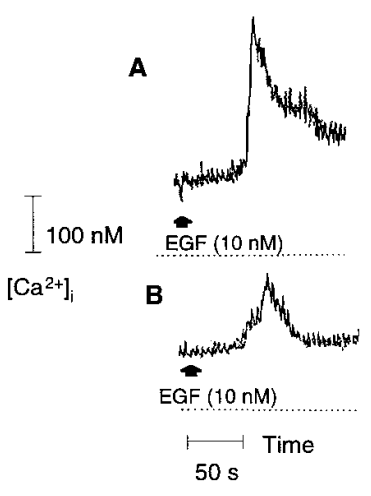

(ii)

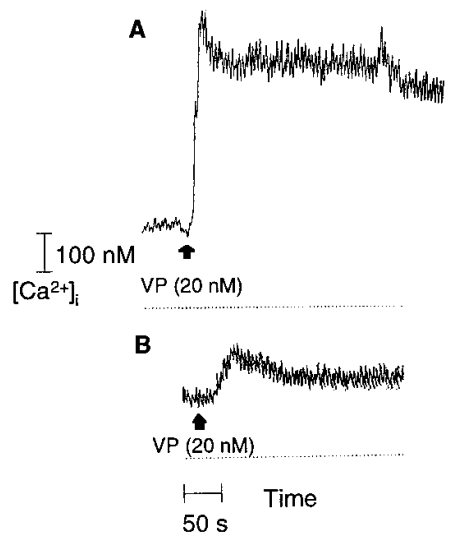

(iii)

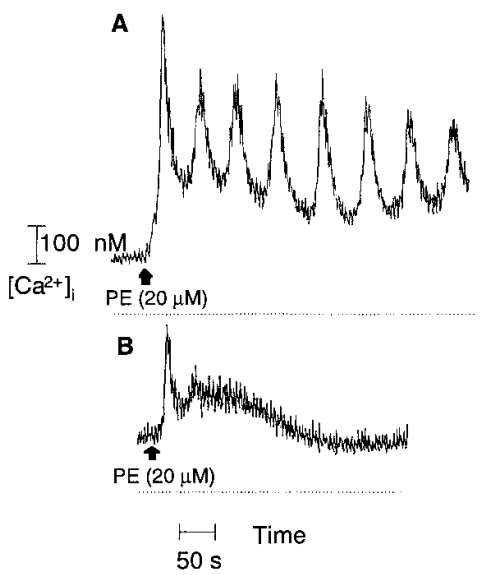

Figure 4. Changes in $\left[\mathrm{Ca}^{2+}\right]_{\mathrm{i}}$ induced by $($ i $)$ EGF, $($ ii) vasopressin, and (iii) phenylephrine in cultured hepatocytes from $(A)$ pair-, and $(B)$ ethanol-fed rats. After culture for $16-18 \mathrm{~h}$, cells were loaded with $5 \mu \mathrm{M}$ fura-2/AM and $\left[\mathrm{Ca}^{2+}\right]_{\mathrm{i}}$ was measured (see Methods). EGF (10 nM), vasopressin $(V P, 20 \mathrm{nM})$, and phenylephrine $(P E, 20 \mu \mathrm{M})$ were added (arrows) to fura-2-loaded hepatocytes in the presence of extracellular $\mathrm{Ca}^{2+}$. This is the direct tracing from the PHOCAL screen in a single experiment, representative of three to seven separate experiments. Both axes are linear. The time indicator $\longmapsto$ corresponds to $50 \mathrm{~s}$, while the $\left[\mathrm{Ca}^{2+}\right]_{\mathrm{i}}$ indicator $\longmapsto$ corresponds to $100 \mathrm{nM}$. 
A

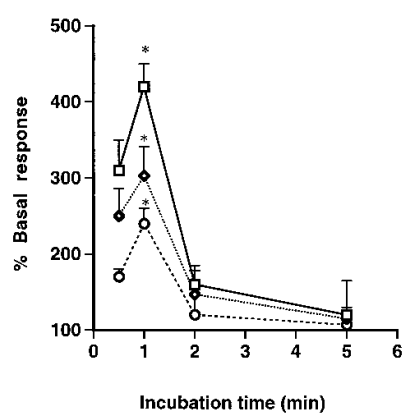

B

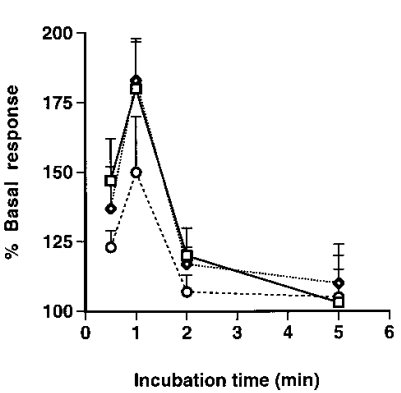

Figure 5. Ins $(1,4,5) P_{3}$ production induced by vasopressin $(V P)$, phenylephrine $(P E)$, and EGF in hepatocytes cultured from pair- and ethanol-fed rats. Hepatocytes were incubated with myo-[1,2- $\left.{ }^{3} \mathrm{H}\right]$ inositol for $15 \mathrm{~h}$. Cells were then incubated with $\mathrm{LiCl}$ and treated with 20 nM VP $(-\square-), 20 \mu \mathrm{M}$ PE $\left(\cdots \vee_{\cdots}\right)$, and $10 \mathrm{nM}$ EGF ( $\left.\cdots-\cdots\right)$ for various times, as described in Methods. Results for both pair- $(A)$ and ethanol-fed rats $(B)$ are expressed as percentage of basal response (Ins $[1,4,5] P_{3}$ produced without addition of hormones). The basal response was $82 \pm 17 \mathrm{dpm} / \mathrm{mg}$ protein for pair-fed rats and $92 \pm 36 \mathrm{dpm} /$ $\mathrm{mg}$ protein for ethanol-fed rats (not significantly different). Values were determined from the mean \pm SD of three to four separate experiments. ${ }^{*} P<0.01$ compared with corresponding values in ethanol-fed rat hepatocytes.

duced by $10 \mu \mathrm{M} \operatorname{Ins}(1,4,5) P_{3}$ were determined in saponin-permeabilized hepatocytes (33). There was no significant difference in the $\left[\mathrm{Ca}^{2+}\right]_{\mathrm{i}}$ induced by $\operatorname{Ins}(1,4,5) P_{3}$ between hepatocytes cultured from pair- and ethanol-fed rats $(506 \pm 32 \mathrm{nM}$ vs $512 \pm$ $18 \mathrm{nM})(P>0.05)$. These results indicate that there was no effect of chronic ethanol feeding on the $\operatorname{Ins}(1,4,5) P_{3}$ receptor governing release of the intracellular $\mathrm{Ca}^{2+}$ store.

Effect of chronic ethanol consumption on intracellular $\mathrm{Ca}^{2+}$ store size. Although the above results indicate that impaired

(i)

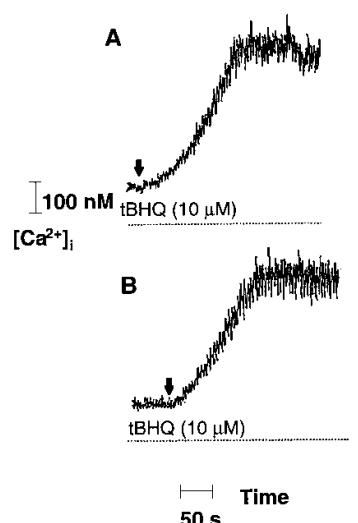

$50 \mathrm{~s}$

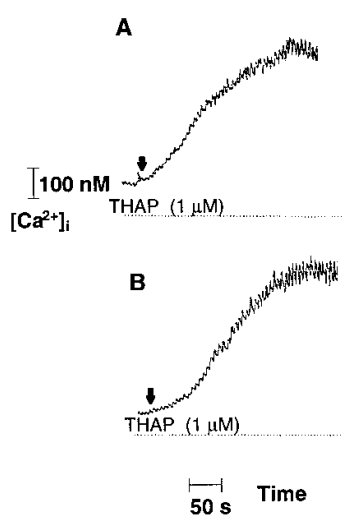

50 s Time

Figure 6. Changes in $\left[\mathrm{Ca}^{2+}\right]_{\mathrm{i}}$ induced by 2,5-di-(tert-butyl)-1,4-hydroquinone $(t B H Q)$ and thapsigargin $(T H A P)$ in cultured rat hepatocytes from pair- and ethanol-fed rats. $10 \mu \mathrm{M}$ tBHQ $(i)$ and $1 \mu \mathrm{M}$ thapsigargin (ii) were added (arrows) to fura-2-loaded hepatocytes. $(A)$ Pair-fed. (B) Ethanol-fed. Each panel is representative of four separate experiments. Relevant experimental details are as described in the legend to Fig. 4.

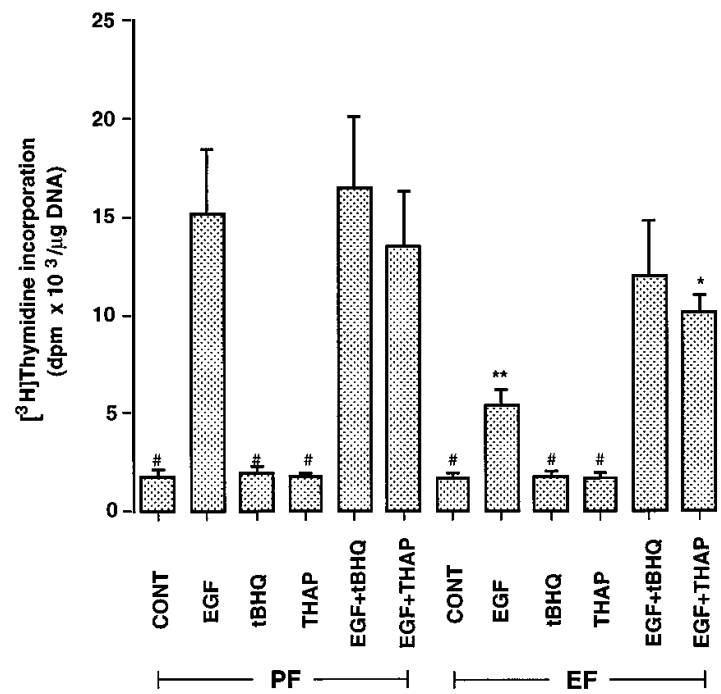

Figure 7. EGF-induced DNA synthesis in hepatocytes cultured from pair- and ethanol-fed rats in the presence of 2,5-di-(tert-butyl)-1,4hydroquinone $(t B H Q)$ or thapsigargin $(T H A P)$. Hepatocytes were treated with $10 \mu \mathrm{M}$ tBHQ or $1 \mu \mathrm{M} T H A P$ for $3 \mathrm{~h}$. CONT, Control, no addition of EGF to medium. $P F$, pair-fed. $E F$, ethanol-fed. $* P<$ 0.05 compared with EGF-treated group in PF rats. $* * P<0.01$ compared with other EGF-treated groups. $\# P<0.001$ compared with all EGF-treated groups. Relevant experimental details are as described in the legend to Fig. 2.

production of $\operatorname{Ins}(1,4,5) P_{3}$ was a possible mechanism for the reduction of $\left[\mathrm{Ca}^{2+}\right]_{\mathrm{i}}$ signaling, it was also possible that the size of the internal $\mathrm{Ca}^{2+}$ pool could be affected by ethanol feeding. We therefore studied whether the quantum of store-releasable $\mathrm{Ca}^{2+}$ in hepatocytes from ethanol-fed rats was sufficient to produce an increase in $\left[\mathrm{Ca}^{2+}\right]_{\mathrm{i}}$ of the same order achieved in normal rat hepatocytes by hormone receptor occupancy. To examine this, a known releaser of the $\operatorname{Ins}(1,4,5) P_{3}$-mobilizable intracellular $\mathrm{Ca}^{2+}$ store, 2,5-di-tert-butylhydroquinone (tBHQ) (34), was added to fura-2-loaded hepatocytes. As shown in Fig. 6 (i), the increase in $\mathrm{Ca}^{2+}$ (reflecting the release of $\mathrm{Ca}^{2+}$ from the intracellular store) induced by $10 \mu \mathrm{M} \mathrm{tBHQ}$ was not significantly different in hepatocytes from pair- and ethanolfed rats $(587 \pm 36 \mathrm{nM}$ vs $596 \pm 42 \mathrm{nM})(P>0.05)$. Similarly, thapsigargin $(1 \mu \mathrm{M})$, another intracellular $\mathrm{Ca}^{2+}$ store mobilizer (35), had the identical effect as tBHQ (Fig. $6[i i])$. Thus, $\left[\mathrm{Ca}^{2+}\right]_{\mathrm{i}}$ induced by $1 \mu \mathrm{M}$ thapsigargin in pair- and ethanol-fed hepatocytes were $587 \pm 22 \mathrm{nM}$ and $572 \pm 45 \mathrm{nM}$, respectively $(P>$ $0.05)$. These results imply that there was no effect of chronic ethanol feeding on the intrahepatic $\mathrm{Ca}^{2+}$ pool size.

Effect of restituting an intracellular $\left[\mathrm{Ca}^{2+}\right]_{i}$ increase on the EGF-stimulated proliferative response of hepatocytes from ethanol-fed rats. If the observed reductions in receptor-operated $\left[\mathrm{Ca}^{2+}\right]_{\mathrm{i}}$ signals contribute mechanistically to the impairment of mitogen-induced hepatocyte proliferation that occurs in ethanol-fed rats, release of intracellular $\left[\mathrm{Ca}^{2+}\right]_{\mathrm{i}}$ stores by a nonIns $(1,4,5) P_{3}$-dependent mechanism should restore the proliferative response. To test this in hepatocytes cultured from chronic ethanol-fed rats, tBHQ $(10 \mu \mathrm{M})$ or thapsigargin (1 $\mu \mathrm{M})$ was added to the cell culture medium with or without EGF. $3 \mathrm{~h}$ later, $\mathrm{tBHQ}$ or thapsigargin was removed by washing and cells were replaced with medium with or without EGF until determination of $\left[{ }^{3} \mathrm{H}\right]$ thymidine incorporation into DNA at $72 \mathrm{~h}$. 
In the absence of EGF, pretreatment with tBHQ or thapsigargin failed to induce $\left[{ }^{3} \mathrm{H}\right]$ thymidine incorporation in hepatocytes from either control rats or ethanol-fed rats (Fig. 7). These results indicate that neither $\mathrm{tBHQ}$ nor thapsigargin has any mitogenic effect on hepatocyte proliferation. In the presence of EGF, tBHQ or thapsigargin also failed to alter $\left[{ }^{3} \mathrm{H}\right]$ thymidine incorporation in hepatocytes from control rats. In hepatocytes from ethanol-fed rats, however, DNA synthesis was significantly increased after treatment with $\mathrm{tBHQ}$ or tharpsigargin (Fig. 7). In the case of tBHQ, the level of $\left[{ }^{3} \mathrm{H}\right]$ thymidine incorporation into DNA was completely restored to levels equivalent to those of pair-fed rat hepatocytes. In the case of thapsigargin, restoration was only partial, because the value remained lower than the EGF-treated pair-fed rat hepatocytes $(P<0.05)$.

\section{Discussion}

The present study in a rat model of long-term ethanol feeding confirms that ethanol inhibits liver regeneration (3-7). The similar impairment of $\left[{ }^{3} \mathrm{H}\right]$ thymidine incorporation into DNA after partial hepatectomy in vivo and after EGF addition in vitro indicates the stability of the alcohol-induced changes and demonstrates the suitability of the hepatocyte culture system to study the molecular basis for this effect. The new finding of this work was that impairment of receptor-operated $\left[\mathrm{Ca}^{2+}\right]_{i}$ signaling was causally related to ethanol-mediated inhibition of liver regeneration. Thus, an increase in $\left[\mathrm{Ca}^{2+}\right]_{i}$ produced by releasing $\mathrm{Ca}^{2+}$ from its intracellular store restored the proliferative response to EGF in hepatocytes from ethanol-fed rats.

The molecular mechanism whereby ethanol inhibits hepatocyte proliferation cannot be explained by loss of the expression or affinity of mitogen receptors. Thus others have found preservation of (or increased) EGF receptors in alcohol-exposured hepatocytes $(36,37)$, a finding confirmed in the present work. Alcohol produces alterations in membrane lipid composition (38) that could affect intracellular signaling in response to the attachment of growth factors and hormones to their cognate cell surface receptors. Thus chronic alcohol consumption has been shown to impair $\left[\mathrm{Ca}^{2+}\right]_{\mathrm{i}}$ signaling in human lymphocytes (39). Further, Sasaki and Wands recently reported that long-term ethanol consumption impairs the transduction of signals from cell surface insulin receptors to intracellular regulatory proteins during liver regeneration (40). In the present study, we found that $\left[\mathrm{Ca}^{2+}\right]_{\mathrm{i}}$ signals induced by addition of EGF, vasopressin or phenylephrine to hepatocytes cultured from ethanol-fed rats were virtually abolished compared to pair-fed controls. EGF, $\alpha_{1}$-adrenergic receptors, and vasopressin have each been ascribed putative roles in the control of liver regeneration $(2,41)$. More importantly, however, it is likely that the failure of cell signaling after exposure to these three receptor ligands indicates a generalized reduction in responsiveness of the liver to mitogens and growth factors.

The results reported here also provide one possible mechanism by which ethanol may impair EGF and hormone-induced $\left[\mathrm{Ca}^{2+}\right]_{\mathrm{i}}$ signal transduction, reduced generation of $\operatorname{Ins}(1,4,5) P_{3}$. It is conceded that there may be other potential mechanisms, such as changes in the sensitivity of $\operatorname{Ins}(1,4,5) P_{3}$ receptors to Ins $(1,4,5) P_{3}$, or a lack of coordination in $\left[\mathrm{Ca}^{2+}\right]_{i}$ responses between individual cells; these possibilities could not be excluded by the present work. However, possible effects of alcohol on the functioning of endoplasmic reticular $\operatorname{Ins}(1,4,5) P_{3}$ receptor or on the size of Ins $(1,4,5) P_{3}$-mobilizable intracellular $\mathrm{Ca}^{2+}$ store appear very unlikely. Thus, using saponin-permeabilized cells, addition of $\operatorname{Ins}(1,4,5) P_{3}$ (in a dose known to saturate Ins $(1,4,5) P_{3}$ receptors) to ethanol-exposed hepatocytes released the same quantum of $\mathrm{Ca}^{2+}$ from the internal store as in normal cells; this indicates operation of the $\operatorname{Ins}(1,4,5) P_{3}$ receptor to release the endoplasmic reticular store, a process that is critical to produce the increase in $\left[\mathrm{Ca}^{2+}\right]_{\mathrm{i}}$ mediated by Ins $(1,4,5) P_{3}(17,42,43)$. tBHQ and thapsigargin have been shown to deplete the same $\mathrm{Ca}^{2+}$ store by inhibiting the microsomal $\mathrm{Ca}^{2+}$ translocase $(34,35)$, so that the increase in $\left[\mathrm{Ca}^{2+}\right]_{\mathrm{i}}$ induced by these compounds reflects the size of the Ins $(1,4,5) P_{3}$-sensitive $\mathrm{Ca}^{2+}$ store. The present observation that both releasers, as well as $\operatorname{Ins}(1,4,5) P_{3}$ itself, produced an identical increase in $\left[\mathrm{Ca}^{2+}\right]_{\mathrm{i}}$ in hepatocytes cultured from ethanolfed and pair-fed rats indicated that ethanol feeding does not appear to change the size of intracellular $\mathrm{Ca}^{2+}$ store.

In several rapidly turning-over cell types, an increase in $\left[\mathrm{Ca}^{2+}\right]_{\mathrm{i}}$ induced by occupation of mitogen and hormone receptors by their cognate ligands appears necessary to trigger cell proliferation (11-15). In hepatocytes, activation of many growth factor and hormone receptors induces transient elevation of $\left[\mathrm{Ca}^{2+}\right]_{\mathrm{i}}$. After attachment to their receptors on the cell membrane, growth factors, such as EGF $(16,44-46)$ and hepatocyte growth factor (46-48), trigger the rapid hydrolysis of $\mathrm{PIP}_{2}$ by activation of PLC $\gamma_{1}$. Hydrolysis of $\mathrm{PIP}_{2}$ produces Ins $(1,4,5) P_{3}$, which is not only responsible for the release of $\mathrm{Ca}^{2+}$ from one or more intracellular stores $(17,43)$, but may also govern $\mathrm{Ca}^{2+}$ entry into the cells through receptor-operated channels (42). Together, these processes result in an increase in $\left[\mathrm{Ca}^{2+}\right]_{\mathrm{i}}$. The present results show impaired production of $\operatorname{Ins}(1,4,5) P_{3}$ despite normal numbers and affinity of EGF receptors. These data lead us to suggest the alcohol-induced defect in $\left[\mathrm{Ca}^{2+}\right]_{\mathrm{i}}$ signaling is at a step that occurs after binding of mitogens to their receptors.

The present observations on the effects of chronic ethanol feeding on $\left[\mathrm{Ca}^{2+}\right]_{\mathrm{i}}$ differ from those of acute alcohol exposure $(49,50)$. Thus it has been shown that high concentrations of ethanol (100 mM or more; but note that the average blood alcohol produced by long-term ethanol feeding in rats is $20 \mathrm{mM}$ ) can increase $\left[\mathrm{Ca}^{2+}\right]_{\mathrm{i}}$ in freshly isolated hepatocytes, and that such concentrations of ethanol stimulate hydrolysis of membrane inositol phosphatides. It should be noted, however, that the nature of hepatocytes studied in suspensions or cultures on some matrices is different from that of well-differentiated hepatocytes. Thus our own observations (Zhang, B.H., and G.C. Farrell, unpublished results) that "acute" ethanol exposure does not increase $\left[\mathrm{Ca}^{2+}\right]_{\mathrm{i}}$ in well-differentiated hepatocytes in primary culture brings into question the physiological relevance of the earlier findings.

Previous studies observing the effects of chronic alcohol consumption on Ins $(1,4,5) P_{3}$ production have also shown conflicting data. Simonsson and Alling (51) observed that inositol phosphate formation in human platelets stimulated with 5-hydroxytryptamine was inhibited in alcoholics. Similarly, Gonzales and Crews using rat liver slices, found that $\operatorname{Ins}(1,4,5) P_{3}$ production stimulated by vasopressin and phenylephrine was suppressed by ethanol consumption for $5 \mathrm{mo}$; there was not an associated change in receptor binding (52). Further, recent work by Spitzer has demonstrated that 8 wk ethanol feeding in rats impairs the PLC-linked generation of inositol polyphosphates induced in rat liver by vasopressin (53). In contrast, 
Hoek et al. (54) reported that a 5-7 wk period of ethanol consumption did not affect hepatic PLC activity. The explanation for these differences may lie in the dose and duration of alcohol exposure. Thus our own observations indicated that $10 \mathrm{wk}$ of feeding lower doses of ethanol was without effect on hepatic regeneration (data not shown), and only by $16 \mathrm{wk}$ at the higher level of alcohol intake was DNA synthesis impaired. It is concluded that the weight of evidence is in favor of high-dose, long-term ethanol exposure inhibiting PLC activity in a range of tissues.

The findings that chronic ethanol feeding was associated with both impairment of EGF-stimulated liver cell proliferation and abrogation of receptor-operated $\left[\mathrm{Ca}^{2+}\right]_{\mathrm{i}}$ signaling are consistent with our hypothesis that interruption of intracellular $\left[\mathrm{Ca}^{2+}\right]_{\mathrm{i}}$ signaling could be the mechanism by which alcohol impairs liver regeneration. From this hypothesis, it was predicted that release of intracellular $\mathrm{Ca}^{2+}$ stores, such as was demonstrated to occur using thapsigargin and tBHQ, should restore the capacity of alcohol-exposed hepatocytes to proliferate. Indeed, incubation of hepatocytes from ethanol-fed rats with 10 $\mu \mathrm{M}$ tBHQ or $1 \mu \mathrm{M}$ thapsigargin for $3 \mathrm{~h}$ did restore their ability to proliferate after exposure to EGF. In the case of tBHQ, such restoration appeared to be complete. The lesser, albeit significant, effect of thapsigargin could be related to a less sustained effect on $\left[\mathrm{Ca}^{2+}\right]_{\mathrm{i}}$ or to the operation of additional mechanisms not identified in the present studies. Whether "replacement" of a $\left[\mathrm{Ca}^{2+}\right]_{\mathrm{i}}$ signal in vivo could restore the proliferative capacity of the intact liver to stimuli such as partial hepatectomy will need to be addressed by additional experiments.

In summary, chronic intake of a high ethanol-containing diet profoundly impaired the capacity of rat liver to regenerate after partial hepatectomy. The continued impairment of EGFstimulated proliferation observed in hepatocytes cultured from ethanol-fed rats provided an experimental system in which to examine the molecular mechanism for alcohol-mediated inhibition of hepatocellular proliferation. Despite normal expression of EGF receptors, the $\left[\mathrm{Ca}^{2+}\right]_{i}$ response to EGF was considerably blunted in hepatocytes cultured from chronic ethanol-fed rats, while the $\left[\mathrm{Ca}^{2+}\right]_{\mathrm{i}}$ signals produced by vasopressin and phenylephrine were virtually abrogated. Impairment of receptor-operated $\operatorname{Ins}(1,4,5) P_{3}$ production was shown to be one of the possible explanations for alcohol-mediated abrogation of hepatocyte $\left[\mathrm{Ca}^{2+}\right]_{\mathrm{i}}$ signaling. Finally, release of the internal $\mathrm{Ca}^{2+}$ pool by chemical means largely or completely reversed the impairment of mitogen-stimulated hepatocyte proliferation observed in ethanol-fed rats. It is concluded that loss of receptor-operated $\left[\mathrm{Ca}^{2+}\right]_{\mathrm{i}}$ signaling is the principal mechanism by which alcohol impairs liver regeneration.

\section{Acknowledgments}

The authors gratefully acknowledge the assistance of Dr. Chris Liddle in establishing the Phocal system, and thank Dr. Andrew Keegan for advice and suggestions on the animal model of chronic ethanol intake.

This work was supported by project grant 910837 of the Australian National Health and Medical Research Council. G.C. Farrell is the Robert W. Storr Professor of Hepatic Medicine.

\section{References}

1. Bucher, N.L.R., and R.A. Malt. 1971. Regeneration of liver and kidney. Little Brown \& Co., Boston.
2. Alison, M.R. 1986. Regeneration of hepatic growth. Physiol. Rev. 66:499541

3. Diehl, A.M., M. Chacon, and P. Wagner. 1988. The effect of chronic ethanol feeding on ornithine decarboxylase activity and liver regeneration. Hepatology. 8:237-242.

4. Diehl, A.M., S.S. Thorgeirsson, and C.J. Steer. 1990. Ethanol inhibits liver regeneration in rats without reducing transcripts of key protooncogenes. Gastroenterology. 99:1105-1112.

5. Duguay, L., D. Coutu, C. Hetu, and J.G. Joly. 1982. Inhibition of liver regeneration by chronic alcohol administration. Gut. 23:8-13.

6. Orrego, H., I.R. Crossley, V. Saldivia, A. Medline, G. Varghese, and Y. Israel. 1981. Long-term ethanol administration and short- and long-term liver regeneration after partial hepatectomy. J. Lab. Clin. Med. 97:221-231.

7. Wands, J.R., E.A. Carter, N.L.R. Bucher, and K.J. Isselbacher. 1979. Inhibition of hepatic regeneration in rats by acute and chronic ethanol intoxication. Gastroenterology. 77:528-531.

8. Carter, E.A., and J.R. Wands. 1985. Ethanol inhibits hormone stimulated hepatocyte DNA synthesis. Biochem. Biophys. Res. Commun. 128:767-774.

9. Carter, E.A., and J.R. Wands. 1988. Ethanol-induced inhibition of liver cell function. I. Effect of ethanol on hormone-stimulated hepatocyte DNA synthesis and the role of ethanol metabolism. Alcohol Clin. Exp. Res. 12:555-562.

10. Lad, P.J., W.T. Shier, H. Skelly, B. de-Hemptinne, and H.L. Leffert. 1982. Adult rat hepatocytes in primary culture. VII. Proliferative and functional properties of cells from ethanol intoxicated animals: evidence for reversible albumin production defect. Alcoholism (Zagreb). 6:72-79.

11. Palombella, V.J., J. Mendelsohn, and J. Vilcek. 1988. Mitogenic action of tumor necrosis factor in human fibroblasts: interaction with epidermal growth factor and platelet-derived growth factor. J. Cell. Physiol. 135:23-31.

12. Hesketh, T.R., J.D.H. Morris, J.P. Moore, and J.C. Metcalfe. 1988. Ca ${ }^{2+}$ and $\mathrm{pH}$ responses to sequential additions of mitogens in single 3T3 fibroblasts: correlations with DNA synthesis. J. Biol. Chem. 263:11879-11886.

13. Sawyer, S.T., and S. Cohen. 1981. Enhancement of calcium uptake and phosphatidylinositol turnover by epidermal growth factor in A-431 cells. Biochemistry. 20:6280-6286.

14. Moolenaar, W.H., L.H. Defize, and S.W. De-Laat. 1986. Ionic signalling by growth factor receptors. J. Exp. Biol. 124:359-373.

15. Gonzalez, F.A., D.J. Gross, L.A. Heppel, and W.W. Webb. 1988. Studies on the increase in cytosolic free calcium induced by epidermal growth factor, serum, and nucleotides in individual A-431 cells. J. Cell. Physiol. 135:269276

16. Ramírez I., F. Tebar, M. Grau, and M. Soley. 1995. Role of heterotrimeric G-proteins in epidermal growth factor signalling. Cell. Signalling. 7:303311

17. Berridge, M.J. 1993. Inositol trisphosphate and calcium signalling. $\mathrm{Na}$ ture (Lond.). 361:315-325.

18. Moolenaar, W.H., L.G.J. Tertoolen, and S.W. de-Laat. 1984. Growth factors immediately raise cytoplasmic free $\mathrm{Ca}^{2+}$ in human fibroblasts. J. Biol. Chem. 259:8066-8069.

19. Rozengurt, E. 1986. Early signals in the mitogenic response. Science (Wash. DC). 234:161-166.

20. Kleinman, H.K., M.L. McGarvey, J.R. Hassell, V.L. Star, F.B. Cannon, G.L. Laurie, and G.R. Martin. 1986. Basement membrane complexes with biological activity. Biochemistry. 25:312-318.

21. Keegan, A.D., R. Martini, and R. Batey. 1995. Ethanol related liver injury in the rat: a model of steatosis, inflammation and pericentral fibrosis. $J$. Hepatol. 23:591-600.

22. Higgins, G.M., and R.M. Anderson. 1931. Experimental pathology of the liver. I. Restoration of the liver of the white rat following partial surgical removal. Arch. Pathol. 12:186-202.

23. Durnam, D.M., and R.D. Palmiter. 1983. A practical approach for quantitating specific mRNA by solution hybridization. Anal. Biochem. 131:385-393.

24. Zhang, B.H., and G.C. Farrell. 1995. Effects of extracellular $\mathrm{Ca}^{2+}$ and $\mathrm{HCO}_{3-}$ on epidermal growth factor-induced DNA synthesis in cultured rat hepatocytes. Gastroenterology. 108:477-486.

25. Bissell, D.M., and P.S. Guzelian. 1980. Phenotypic stability of adult rat hepatocytes in primary monolayer culture. Annu. NY. Acad. Sci. 349:85-98.

26. Shi, Y.E., and J.D. Yager. 1989. Effects of the liver tumor promoter ethinyl estradiol on epidermal growth factor-induced DNA synthesis and epidermal growth receptor levels in cultured rat hepatocytes. Cancer Res. 49:35743580 .

27. Scatchard, G. 1949. The attractions of proteins for small molecules and ions. Ann. N. Y. Acad. Sci. 51:660-672.

28. Grynkiewicz, G., M. Poenie, and R.Y. Tsien. 1985. A new generation of $\mathrm{Ca}^{2+}$ indicators with greatly improved fluorescence properties. J. Biol. Chem. 260:3440-3450.

29. Hansen, C.A., S. Mah, and J.R. Williamson. 1986. Formation and metabolism of inositol 1,3,4,5-tetrakisphosphate in liver. J. Biol. Chem. 261:8100 8103.

30. Lowry, O.H., N.J. Rosebrough, A.L. Farr, and R.J. Randall. 1951. Protein measurement with the Folin phenol reagent. J. Biol. Chem. 193:265-275.

31. Johnson, R.M., and J.C. Garrison. 1987. Epidermal growth factor and angiotensin II stimulate formation of inositol 1,4,5- and 1,3,4-trisphosphate in 
hepatocytes. Differential inhibition by pertussis toxin and phorbol 12-myristate 13-acetate. J. Biol. Chem. 262:17285-17293.

32. Thomas, A.P., J. Alexander, and J.R. Williamson. 1984. Relationship between inositol polyphosphate production and the increase of cytosolic free $\mathrm{Ca}^{2+}$ induced by vasopressin in isolated hepatocytes. J. Biol. Chem. 259:55745584.

33. Combettes, L., B. Berthon, E. Doucet, S. Erlinger, and M. Claret. 1989. Characteristics of bile acid-mediated $\mathrm{Ca}^{2+}$ release from permeabilized liver cells and liver microsomes. J. Biol. Chem. 264:157-167.

34. Kass, G.E.N., S.K. Duddy, G.A. Moore, and S. Orrenius. 1989. 2,5-Di(tert-butyl)-1,4-benzohydroquinone rapidly elevates cytosolic $\mathrm{Ca}^{2+}$ concentration by mobilizing the inositol 1,4,5-trisphosphate-sensitive $\mathrm{Ca}^{2+}$ pool. J. Biol. Chem. 264:15192-15198.

35. Glennon, M.C., G. St. J. Bird, C.-Y. Kwan, and J.W. Putney Jr. 1992. Actions of vasopressin and the $\mathrm{Ca}^{2+}$-ATPase inhibitor, thapsigargin, on $\mathrm{Ca}^{2+}$ signalling in hepatocytes. J. Biol. Chem. 267:8230-8233.

36. Henderson, G.I., G.S. Baskin, J. Horbach, P. Porter, and S. Schenker. 1989. Arrest of epidermal growth factor-dependent growth in fetal hepatocytes after ethanol exposure. J. Clin. Invest. 84:1287-1294.

37. Patel, B.C., C. D'Arville, M. Iwahashi, and F.R. Simon. 1991. Impairment of hepatic insulin receptors during chronic ethanol administration. Am. J. Physiol. 261:G199-205.

38. Lieber, C.S. 1994. Alcohol and the liver: 1994 update. Gastroenterology. 106:1085-1105.

39. Stefanini, G.F., E. Castelli, F.G. Foschi, S. Hrelia, P.L. Biagi, M. Celadon, A. Bordoni, and G. Gasbarrini. 1994. Alcoholics' impaired lymphocyte response is caused by alcohol. Gastroenterology. 106:1724-1726.

40. Sasaki, Y., and J.R. Wands. 1994. Ethanol impairs insulin receptor substrate-1 mediated signal transduction during rat liver regeneration. Biochem. Biophys. Res. Commun. 199:403-409.

41. Michalopoulos, G.K. 1990. Liver regeneration: molecular mechanisms of growth control. FASEB J. 4:176-187.

42. Putney, J.W., Jr. 1990. Capacitative calcium entry revisited. Cell Calcium. 11:611-624.

43. Williamson, J.R., R.H. Cooper, S.K. Joseph, and A.P. Thomas. 1985. Inositol trisphosphate and diacylglycerol as intracellular second messengers in liver. Am. J. Physiol. 248:C203-C216.

44. Liang, M., and J.C. Garrison. 1992. Epidermal growth factor activates phospholipase $\mathrm{C}$ in rat hepatocytes via a different mechanism from that in A431 or rat 1hER cells. Mol. Pharmacol. 42:743-752.

45. Yang, L., A.M. Camoratto, G. Baffy, S. Raj, D.R. Manning, and J.R. Williamson. 1993. Epidermal growth factor-mediated signalling of $\mathrm{G}_{\mathrm{i}}$-protein to activation of phospholipases in cultured rat hepatocytes. J. Biol. Chem. 268: 3739-3746.

46. Mine, T., I. Kojima, E. Ogata, and T. Nakamura. 1991. Comparison of effects of HGF and EGF on cellular calcium in rat hepatocytes. Biochem. Biophys. Res. Commun. 181:1173-1180.

47. Baffy, G., L. Yang, G.K. Michalopoulos, and J.R. Williamson. 1992 Hepatocyte growth factor induces calcium mobilization and inositol phosphate production in rat hepatocytes. J. Cell. Physiol. 153:332-339.

48. Kaneko, A., N. Hayashi, H. Tsubouchi, Y. Tanaka, T. Ito, Y. Sasaki, H Fusamoto, Y. Daikuhara, and T. Kamada. 1992. Intracellular calcium as a second messenger for human hepatocyte growth factor in hepatocytes. Hepatology. 15:1173-1178.

49. Hoek, J. B., A.P. Thomas, T.A. Rooney, K. Higashi, and E. Rubin. 1992 Ethanol and signal transduction in the liver. FASEB J. 6:2386-2396.

50. 50. Reinlib, L., E. Akinshola, J. J. Potter, and E. Mezey. 1990. Ethanolinduced increase in $\left[\mathrm{Ca}^{2+}\right]$ and in inositol $(1,4,5)$ trisphosphate in rat hepatocytes. Biochem. Biophys. Res. Commun. 173:774-780.

51. Simonsson, P., and C. Alling. 1988. The 5-hydroxytryptamine stimulated formation of inositol phosphate is inhibited in platelets from alcoholics. Life Sci. 42:385-391.

52. Gonzales, R.A., and F.T. Crews. 1991. Chronic ethanol inhibits receptor-stimulated phosphoinositide hydrolysis in rat liver slices. Alcohol. 8:131136.

53. Spitzer, J.A. 1994. Vasopressin-initiated signal transduction is impaired in hepatocytes of chronically alcoholic rats in the absence or presence of LPS treatment. Hepatology. 20:182A.

54. Hoek, J.B., T.F. Taraschi, K. Higashi, E. Rubin, and A.P. Thomas. 1990 Phospholipase $\mathrm{C}$ activation by ethanol in rat hepatocytes is unaffected by chronic ethanol feeding. Biochem. J. 272:59-64. 